Date: $\quad$ June 2, 2016

Submitted to: Journal of Hazardous Materials

\title{
Removal of copper from water using a thermally regenerative electrodeposition battery
}

\author{
Mohammad Rahimi ${ }^{1}$, Zachary Schoener ${ }^{2}$, Xiuping Zhu ${ }^{3}$, Fang Zhang ${ }^{4}$, Christopher A. Gorski ${ }^{3}$, \\ Bruce Logan,
}

\begin{abstract}
A thermally regenerative ammonia battery (TRAB) recently developed for electricity generation using waste heat was adapted and used here as a treatment process for solutions containing high concentrations of copper ions. Copper removal reached a maximum of $77 \%$ at an initial copper concentration $\left(C_{i}\right)$ of $0.05 \mathrm{M}$, with a maximum power density $(P)$ of $31 \mathrm{~W} \mathrm{~m}^{-2}$-electrode area. Lowering the initial copper concentration decreased the percentage of copper removal from $51 \%$ $\left(C_{i}=0.01 \mathrm{M}, P=13 \mathrm{~W} \mathrm{~m}^{-2}\right)$ to $2 \%\left(C_{i}=0.002 \mathrm{M}, P=2 \mathrm{~W} \mathrm{~m}^{-2}\right)$. Although the final solution may require additional treatment, the adapted TRAB process removed much of the copper while producing electrical power that could be used in later treatment stages. These results show that the adapted TRAB can be a promising technology for removing copper ions and producing electricity by using waste heat as a highly available and free source of energy at many industrial sites.
\end{abstract}

Keywords: copper removal; electrodeposition; various concentration of copper; waste heat 


\section{Introduction}

Wastewaters from industries that are involved in mining, electroplating, or smelting operations contain various dissolved metals, which can be harmful to the environment when released without treatment $[1,2]$. Various techniques have been used to treat these industrial wastewaters, including chemical precipitation [3], absorption [4, 5], biosorption [6-9], photocatalytic removal [10-12], ion exchange [13], membrane separation [14, 15], bioelectrochemical systems [16, 17], electrodeposition/reduction [18, 19], and electrocoagulation (EC) [20-22]. Electrocoagulation is a water treatment process that uses an electric current applied across one or two metal electrodes to remove metals such as copper, nickel, zinc and chromium [23, 24]. Electrocoagulation offers many benefits over other technologies, including simple operation, high removal efficiency, and low sludge formation [25-27]. However, a major disadvantage of EC is that it requires substantial electrical power, in proportion to the initial concentration of heavy metals [27]. Therefore, reducing the concentration of heavy metals prior to EC treatment would decrease overall electrical power demands.

A method was recently proposed to produce electricity from low-grade waste heat, called a thermally regenerative ammonia battery (TRAB) [28, 29]. In a TRAB, electrical power is obtained from the formation of metal ammine complexes, which are produced by adding ammonia to the anolyte, but not to the catholyte, of a battery consisting of two copper electrodes in a copper-nitrate electrolyte. The added ammonia generates a potential difference between the electrodes according to the reactions [30]:

$$
\begin{array}{ll}
\text { Cathode: } \mathrm{Cu}^{2+}{ }_{(\text {aq })}+2 \mathrm{e}^{-} \rightarrow \mathrm{Cu}_{(\mathrm{s})} & E^{0}=+0.340 \mathrm{~V} \\
\text { Anode: } \mathrm{Cu}_{(\mathrm{s})}+4 \mathrm{NH}_{3(\text { (aq) }} \rightarrow \mathrm{Cu}\left(\mathrm{NH}_{3}\right)_{4}{ }^{2+}{ }_{(\mathrm{aq})}+2 \mathrm{e}^{-} & E^{0}=-0.04 \mathrm{~V}
\end{array}
$$



After discharging the cell and generating electrical power, ammonia is separated from the anolyte using conventional distillation using low-grade waste heat, as described in our previous investigations (Figure S1) [31, 32]. The distilled ammonia is then added to the other electrolyte chamber for the next discharge cycle. While discharging the battery results in copper loss from the anode, the electrode can be regenerated when the ammonia is added to the other chamber, where copper will be re-deposited back onto the electrode.

A new approach for copper removal based on the TRAB was examined here to simultaneously remove copper and generate electricity. In this process, which we refer to as a thermally regenerative electrodeposition battery (TREB), solutions containing copper ions is introduced to both chambers of a TREB, then ammonia is added only to the anolyte, and not the cathode chamber (treatment chamber). During battery discharge, copper ions are reduced to copper metal at the cathode and are removed from solution, accomplishing treatment of the water in the cathode chamber. Once the electrical power is discharged, the treated waste is collected into a low concentration tank either for reuse, or additional treatment in an EC cell to reduce copper concentrations to that allowable for discharge. The electricity generated by the TREB can be used as a power source for the EC cell, making the overall process more economical. Because the anode corrodes occurs during this process, the anolyte will have an increased concentration of copper. However, this high copper ion concentration anolyte can be collected and further used in a typical TRAB to harvest additional electrical energy from waste heat. It is also possible that copper could be extracted from this high concentration stream in the copper electroplating industrial units. The electrodes are alternatively operated as cathode and anodes during the treatment to maintain the copper on the electrodes (Figure 1). 


\section{Experimental Section}

\subsection{TREB construction and operation}

The TREB was constructed as previously described $[28,29]$. The battery consisted of a cathode and an anode chamber, each $4 \mathrm{~cm}$ long and $3 \mathrm{~cm}$ in diameter, separated by an anion exchange membrane (AEM; Selemion AMV, Asashi glass, Japan) with effective surface area of $7 \mathrm{~cm}^{-2}$. Two $0.8 \pm 0.05 \mathrm{~cm} \times 2 \pm 0.05 \mathrm{~cm}$ pieces of copper mesh $(50 \times 50 \mathrm{mesh}$; McMaster-Carr, $\mathrm{OH})$ connected by copper wire were used as the electrodes, with each electrode placed $1 \mathrm{~cm}$ away from the membrane. In order to monitor the electrode potentials, two $\mathrm{Ag} / \mathrm{AgCl}$ reference electrodes (+0.211 V vs. SHE; RE-5B; BASi) were inserted $1 \mathrm{~cm}$ away from each electrode (2 $\mathrm{cm}$ away from the membrane). The catholyte was mixed using a magnetic stirrer $(6.4 \times 15.9 \mathrm{~mm}$; 
VWR) at $600 \mathrm{rpm}$. Previous investigations showed that stirring the catholyte improved the power generation, due to better mass transfer of ions to the electrode [28].

The copper solution was prepared by dissolving different concentrations of $\mathrm{CuSO}_{4}$ (SigmaAldrich) in deionized water. The supporting electrolyte, $\left(\mathrm{NH}_{4}\right)_{2} \mathrm{SO}_{4}$ (Sigma-Aldrich), was added to increase the solution's conductivity. Ammonium hydroxide (2 M final concentration; $5 \mathrm{~N}$ solution, Sigma-Aldrich) was added to the anolyte to form the copper ammonia complex and create the potential difference between the cathode and anode chambers. The initial anolyte $\mathrm{pH}$ was 9.7, consistent with that expected for the addition of a $2 \mathrm{M}$ solution of ammonia. The cell was operated with a fixed external resistance that produced the highest power (based on polarization data) for a whole batch cycle, which ended when the cell voltage decreased to $<10$ $\mathrm{mV}$. All experiments were conducted at $30^{\circ} \mathrm{C}$ in a constant temperature room.

\subsection{Measurements and calculations}

In the cathode chamber, the removal of copper occurs due to deposition on the copper electrode. Copper removal was calculated based on the mass change of the electrode during discharge of the TREB as:

$$
\text { Removal }=\frac{\left(m_{f, c}-m_{0, c}\right)}{C_{i} M V} \times 100
$$

where $m_{0, c}$ and $m_{f, c}$ are cathode electrode masses before and after treatment, $C_{i}$ is the initial concentration of $\mathrm{Cu}(\mathrm{II})$ in the solution, $M$ is the molecular weight of copper $\left(63.55 \mathrm{~g} \mathrm{~mol}^{-1}\right)$, and $V$ is the volume of cathode chamber $\left(28 \pm 1 \mathrm{~cm}^{3}\right)$. Coulombic efficiency of the cathode (CCE) was calculated as the ratio between actual produced charge and the theoretical amount of charge based on the mass change of the electrode, as:

$$
\operatorname{CCE}(\%)=\frac{\left(m_{f, c}-m_{0, c}\right)}{\frac{Q M}{2 F}} \times 100
$$


where $Q$ is the total charge transferred (C), and $F$ is the Faraday constant $\left(96485 \mathrm{C} \mathrm{mol}^{-1}\right)$. The mass was measured using an analytical balance with a precision of $0.0001 \mathrm{~g}$. Considering the uncertainties of the volume and analytical balance, the uncertainty of Rem was $2 \%$, while that for $C C E$ were less than $0.01 \%$.

Polarization tests were performed using a potentiostat (model 1470E, Solatron Analytical, Hampshire, England) to measure the cell voltage $(U)$, and each electrode potential in a constant temperature room. External resistances were switched every $5 \min$ from 40.9 to $1 \Omega$ [for 0.1 and $0.05 \mathrm{M} \mathrm{Cu}(\mathrm{II})$ ], 61.2 to $8.2 \Omega$ [for $0.01 \mathrm{M} \mathrm{Cu}(\mathrm{II})$ ], and 200 to $60 \Omega$ [for $0.002 \mathrm{M} \mathrm{Cu(II)]} \mathrm{in}$ decreasing order. Both current density $\left(i=U / R A, \mathrm{~A} \mathrm{~m}^{-2}\right)$, and power density $\left(\mathrm{P}=\mathrm{U}^{2} / \mathrm{RA}, \mathrm{W} \mathrm{m}^{-2}\right)$ were normalized to a single electrode projected surface area of $1.6 \mathrm{~cm}^{2}$ [38]. Before connecting the external resistance to the cell, the open circuit potential of the cathode was recorded for 5 mins. The potential of the cathode chamber was calculated using the Nernst equation at various initial concentrations of $\mathrm{Cu}$ (II) in the catholyte (Equation S1; Figure S2). To calculate the theoretical potential by the Nernst equation, the $\mathrm{Cu}(\mathrm{II})$ ion activities were estimated using the OLI Studio software (Cedar Knolls, NJ).

The total charge transferred over the entire copper removal process was calculated by integrating the current-time profile $Q=\int I t_{s}$, where $Q$ is the total charge (C), $I$ the current (A), and $t_{s}$ time (s). The energy density, normalized to the total electrolyte volume $\left(E, \mathrm{Wh} \mathrm{m}^{-3}\right)$, was calculated as $E=\int U I t_{h} / V$, where $U$ is the voltage (V), I the current (A), $t_{h}$ the cycle time (h), and $V$ the total volume $(2 \times 28 \mathrm{~mL})$. Based on possible variations in the volume of the solutions, the experimental errors for the calculated energy densities were less than $4 \%$.

After discharging the TREB, the battery was recharged by separating ammonia from the anolyte effluent and re-dissolving it in the catholyte. In practice, low-grade waste heat $\left(<100{ }^{\circ} \mathrm{C}\right)$ 
could be used for this process, for example by using a distillation column with a reboiler and condenser temperature of 70.4 and $43.3{ }^{\circ} \mathrm{C}$, respectively. Previous simulation results indicated that $97 \%$ of ammonia could be recovered during this separation [28, 29].

\section{Results and Discussion}

\subsection{Copper removal at different concentration of copper in the solutions}

The copper removal efficiency (\%) strongly depended on the initial $\mathrm{Cu}(\mathrm{II})$ concentration. Copper removal was $>50 \%$ when initial $\mathrm{Cu}(\mathrm{II})$ concentrations were $\geq 0.01 \mathrm{M}$ using a $1 \mathrm{M}\left(\mathrm{NH}_{4}\right)_{2} \mathrm{SO}_{4}$ electrolyte for both the anolyte and catholyte. The highest removal was achieved at a concentration of $0.05 \mathrm{M}(77 \%)$. Treatment of solutions containing $0.002 \mathrm{M}$ or less $\mathrm{Cu}(\mathrm{II})$ had $<2 \%$ copper removal, resulting in a very low rate of copper deposition and copper recovery under these conditions (Figure 2a).

Low recoveries of copper from the catholyte at relatively low $\mathrm{Cu}(\mathrm{II})$ concentrations were due to unwanted side reactions. The cathodic coulombic efficiency (CCE), which is the ratio of the produced current to the theoretical amount of current based on the change in the mass of the electrode, can be used to evaluate the relative importance of the electrodeposition reaction for copper ions compared to other possible side reactions in the cathode chamber. A CCE of $<100 \%$ (range of 2 to $89 \%$ ) was obtained in all experiments, confirming side reactions occurred in the catholyte (Figure 2b). We expected that the main side reactions involved the formation of a $\mathrm{Cu}(\mathrm{OH})_{2}$ precipitate, and the formation of copper ammine complexes $\left(\mathrm{Cu}^{2+}+\mathrm{nNH}_{3} \rightarrow\right.$ $\left.\left[\mathrm{Cu}\left(\mathrm{NH}_{3}\right)_{\mathrm{n}}\right]^{2+} ; \mathrm{n}=1,2,3,4\right)$ in the cathode chamber. These reactions and their relevant equilibrium constants are [39]:

$$
\mathrm{Cu}(\mathrm{OH})_{2(\mathrm{~s})}=\mathrm{Cu}^{2+}+2 \mathrm{OH}^{-} \quad, \quad \mathrm{pK}_{\mathrm{sp}}=19.36
$$




$$
\begin{array}{lll}
\mathrm{NH}_{4}^{+}=\mathrm{NH}_{3}+\mathrm{H}^{+} & , & \mathrm{pK}_{\mathrm{a}}=9.25 \\
\mathrm{Cu}^{2+}+\mathrm{NH}_{3}=\left[\mathrm{Cu}\left(\mathrm{NH}_{3}\right)\right]^{2+} & , & \mathrm{pK}_{1}=-4.25 \\
{\left[\mathrm{Cu}\left(\mathrm{NH}_{3}\right)\right]^{2+}+\mathrm{NH}_{3}=\left[\mathrm{Cu}\left(\mathrm{NH}_{3}\right)_{2}\right]^{2+}} & , & \mathrm{pK}_{2}=-3.61 \\
{\left[\mathrm{Cu}\left(\mathrm{NH}_{3}\right)_{2}\right]^{2+}+\mathrm{NH}_{3}=\left[\mathrm{Cu}\left(\mathrm{NH}_{3}\right)_{3}\right]^{2+}} & , & \mathrm{pK}_{3}=-2.98 \\
{\left[\mathrm{Cu}\left(\mathrm{NH}_{3}\right)_{3}\right]^{2+}+\mathrm{NH}_{3}=\left[\mathrm{Cu}\left(\mathrm{NH}_{3}\right)_{4}\right]^{2+} \quad,} & \mathrm{pK}_{4}=-2.24
\end{array}
$$

\begin{abstract}
When the solution had a low copper ion concentration of $0.002 \mathrm{M}$, the main side reaction would likely be formation of a $\mathrm{Cu}(\mathrm{OH})_{2}$ precipitate, primarily due to the higher initial $\mathrm{pH}$ of the catholyte (Figure S3). During experiments at this copper concentration, we observed formation of precipitates. Based on our calculations, the observed pale blue precipitates were likely $\mathrm{Cu}(\mathrm{OH})_{2}$ (Table S1). A higher $\mathrm{pH}$ should also result in a shift in the $\mathrm{NH}_{4}^{+} / \mathrm{NH}_{3}$ acid/base reactions towards $\mathrm{NH}_{3}$ formation side, resulting in greater formation of different copper ammine complexes, as shown by equations $6-10$. At higher copper concentrations $(>0.01 \mathrm{M})$, however, copper ions are less involved in the side reactions, mainly due to the lower $\mathrm{pH}$ of catholyte. Therefore, the loss of free $\mathrm{Cu}(\mathrm{II})$ ions to ammonia complexes, as well as formation of a $\mathrm{Cu}(\mathrm{OH})_{2}$ precipitate rather than current generation, resulted in limited copper ion removal from the lower concentration solutions $(<0.01 \mathrm{M})$.
\end{abstract}

The highest CCE was obtained at a copper concentration of $0.05 \mathrm{M}(\sim 90 \%)$, confirming most of the current was consumed by $\mathrm{Cu}$ (II) ion deposition onto the cathode electrode. The highest CCE for a copper concentration of $0.05 \mathrm{M}$ was the main reason for the highest percentage of copper removal at this copper concentration.

\title{
3.2. Power production with different concentration of copper ions
}


Increasing the initial $\mathrm{Cu}(\mathrm{II})$ concentration from $0.002 \mathrm{M}$ to $0.1 \mathrm{M}$ improved the power production from $2 \mathrm{~W} \mathrm{~m}^{-2}$-electrode area to $37 \mathrm{~W} \mathrm{~m}^{-2}$-electrode area (Figure 3). This increase in power was due to more positive cathodic potentials during battery discharge. Power generation was examined over a complete discharge cycle (defined as a final cell voltage $<10 \mathrm{mV}$ ), at the external resistance that produced the maximum power density (5.6 $\Omega$ for $0.1 \mathrm{M}$ and $0.05 \mathrm{M}, 20.6$ $\Omega$ for $0.01 \mathrm{M}$, and $99.6 \Omega$ for $0.002 \mathrm{M}$; Figure 3). The reason the optimum external resistance varied was likely due to the different copper ion redox activity (i.e., electron transfer ability) at different concentrations of copper [40]. The discharge time was reduced by decreasing the initial $\mathrm{Cu}$ (II) concentration in the solution, mainly due to the $\mathrm{Cu}$ (II) side reactions as well as lower availability of copper ions in the catholyte (Figure 4). When the initial concentration of copper ions was decreased, the solution $\mathrm{pH}$ increased from 3.8 for $0.1 \mathrm{M} \mathrm{Cu}(\mathrm{II})$ to 4.8 for $0.002 \mathrm{M}$ $\mathrm{Cu}(\mathrm{II})$, which would result an increased formation of $\mathrm{Cu}(\mathrm{OH})_{2}$ precipitates during treatment due to the higher $\mathrm{pH}$, consistent with visual observations of formation of a light blue solid in the reactor with these changes [28]. The different power production curves were mostly caused by the changes in cathode potentials. The cathode potential initially increased and reached a maximum, where power density reached a maximum as well, and then it started to become more negative. In contrast, there was an insignificant change in the anode potential over time (Figure $4 b)$.

\subsection{Total charge transfers and energy densities}

Decreasing the $\mathrm{Cu}$ (II) initial concentration from $0.1 \mathrm{M}$ to $0.002 \mathrm{M}$ reduced the total charge transfer, based on coulombic recoveries decreasing from 400 coulombs (C) to $5 \mathrm{C}$ (Figure 5). This decrease was due to lower copper deposition rates at lower initial $\mathrm{Cu}(\mathrm{II})$ concentrations. 
The energy densities produced by the TREB during the treatment increased with the $\mathrm{Cu}(\mathrm{II})$ initial concentration, similar to the increases in maximum power densities obtained in polarization tests. The highest energy density produced by the treatment system was $280 \mathrm{Wh} \mathrm{m}^{-3}$ at an initial $\mathrm{Cu}$ (II) concentration of $0.1 \mathrm{M}$, which is $\sim 60 \%$ of the energy produced in a previous TRAB with nitrate salts in the electrolyte, at the same copper concentration [28], rather than sulfate salts used here (Figure 5). The higher energy densities obtained here for higher copper concentrations were due to the higher discharge voltages and the total charge transferred $(\mathrm{W}=\mathrm{QU}$, where $\mathrm{W}$ is energy, $\mathrm{Q}$ the charge, and $\mathrm{U}$ the voltage).

\section{Reuse of the high concentration effluent}

Another possible concern is the increased copper concentration in the anolyte. While the TREB process can produce an effluent catholyte with a reduced copper concentration, the anolyte copper concentration will increase over time. To minimize the volume of the anolyte used, the solution in the anode compartment could remain in the chamber for a several batches of catholyte (Figure S4). To examine the reuse of the anolyte, a solution with a $\mathrm{Cu}(\mathrm{II})$ concentration of $0.05 \mathrm{M}$ was examined in the TREB process, with the anolyte used for four batches of catholyte. For the third batch of catholyte, there was $68 \%$ copper removal and a maximum power density of $26 \mathrm{~W} \mathrm{~m}^{-2}$, similar to that obtained in the first batch cycle (Removal $=77 \% ; P=33 \mathrm{~W} \mathrm{~m}^{-}$

${ }^{2}$ ). However, for the fourth batch cycle, both copper removal and power substantially decreased (23\% removal, $12 \mathrm{~W} \mathrm{~m}^{-2}$ ) (Figure 6). After each batch, the concentration of copper ion in the anolyte increased, resulting in the enhancement of copper ammonia complex concentration $\left(\mathrm{Cu}\left(\mathrm{NH}_{3}\right)_{4}{ }^{2+}\right)$ and a decrease in the concentration of ammonia (Equation 2). The benefit of a higher copper complex concentration in the anolyte with each cycle, which could have increased 
the cell potential, was offset in the fourth batch cycle by a reduction in the ammonia concentration in the anolyte. As a result, there was a decrease in the power (Equation S2), and less copper removal.

\section{Outlook}

The TREB process was shown to simultaneously remove copper and generates power, but the copper was not reduced to levels sufficient for water discharge (50-80 $\mu \mathrm{M})$ [41]. However, the copper remaining in the water following TREB treatment could be reduced to levels suitable for discharge using a standard electrocoagulation treatment system. The advantages of using the TREB process to first treat a wastewater is increased recovery of copper, the use of waste heat which recovers copper without the use of electrical power, electrical power generation, and less copper in a waste sludge. In demonstrating the concept of copper removal using TREB, only simple solutions were used here as they contained only a copper sulfate electrolyte. Actual industrial wastewaters will contain other constituents, notably chloride ions, which could impact treatment efficiency. The effect of these other anions and cations on the process will require further study.

\section{Conclusions}

The TREB process was shown to be a potential method of treatment, with $>30 \%$ copper ion removal from solutions containing copper ions $(>0.01 \mathrm{M})$, and production of up to $25 \mathrm{~W} \mathrm{~m}^{-2}$ based on charging the cell with ammonia solutions prepared using low-grade waste heat. In addition, the produced high concentration effluent can be used for a several number of batches, minimizing the volume of anolyte used. Overall, using a low-grade waste-to-electricity TREB 
system for removal of copper ions from solution represents a promising approach for decreasing the energy requirements of current treatment plants and improved copper recovery.

\section{Acknowledgments}

The authors would like to thank David Jones for his assistance. The research was supported by award CBET-1464891 from the National Science Foundation.

\section{Appendix A. Supplementary data}

Supplementary data associated with this article can be found in a separate file.

\section{References}

[1] F. Fu, Q. Wang, Removal of heavy metal ions from wastewaters: A review, J. Environ. Manage., 92 (2011) 407-418.

[2] I. Heidmann, W. Calmano, Removal of $\mathrm{Zn}(\mathrm{II}), \mathrm{Cu}(\mathrm{II}), \mathrm{Ni}(\mathrm{II}), \mathrm{Ag}(\mathrm{I})$ and $\mathrm{Cr}(\mathrm{VI})$ present in aqueous solutions by aluminium electrocoagulation, J. Hazard. Mater., 152 (2008) 934-941.

[3] A.H. Sulaymon, A.A.H. Faisal, Q.M. Khaliefa, Simultaneous adsorption-precipitation characterization as mechanisms for metals removal from aqueous solutions by cement kiln dust (CKD), Desalin. Water Treat., 57 (2016) 819-826.

[4] Y.L. Zhang, J. Yang, X.J. Yu, Q.L. Wang, W.Q. Huang, Adsorption technology and mechanism of Cu and $\mathrm{CN}$ - from cyanide waste water on modified peanut shell, Synth. React. Inorg. Met.-Org. Nano-Metal Chem., 46 (2016) 561-569.

[5] M. Aflaki Jalali, A. Dadvand Koohi, M. Sheykhan, Experimental study of the removal of copper ions using hydrogels of xanthan, 2-acrylamido-2-methyl-1-propane sulfonic acid, montmorillonite: Kinetic and equilibrium study, Carbohydrate Polymers, 142 (2016) 124-132.

[6] A. Witek-Krowiak, R.G. Szafran, S. Modelski, Biosorption of heavy metals from aqueous solutions onto peanut shell as a low-cost biosorbent, Desalination, 265 (2011) 126-134.

[7] A. Robalds, G.M. Naja, M. Klavins, Highlighting inconsistencies regarding metal biosorption, J. Hazard. Mater., 304 (2016) 553-556.

[8] A. Chan, H. Salsali, E. McBean, Heavy metal removal (copper and zinc) in secondary effluent from wastewater treatment plants by microalgae, ACS Sustainable Chem. Eng., 2 (2014) 130-137.

[9] S. Amirnia, M.B. Ray, A. Margaritis, Copper ion removal by Acer saccharum leaves in a regenerable continuous-flow column, Chem. Eng. J., 287 (2016) 755-764.

[10] H.D. Doan, M. Saidi, Simultaneous removal of metal ions and linear alkylbenzene sulfonate by combined electrochemical and photocatalytic process, J. Hazard. Mater., 158 (2008) 557-567.

[11] K. Kabra, R. Chaudhary, R.L. Sawhney, Solar photocatalytic removal of metal ions from industrial wastewater, Environ. Prog., 27 (2008) 487-495.

[12] M. Feilizadeh, M. Vossoughi, S.M.E. Zakeri, M. Rahimi, Enhancement of efficient Ag-S/TiO2 nanophotocatalyst for photocatalytic degradation under visible light, Ind. Eng. Chem. Res., 53 (2014) 9578-9586. 
[13] M.D. Victor-Ortega, J.M. Ochando-Pulido, A. Martinez-Ferez, Thermodynamic and kinetic studies on iron removal by means of a novel strong-acid cation exchange resin for olive mill effluent reclamation, Ecol. Eng., 86 (2016) 53-59.

[14] J. Song, H. Oh, H. Kong, J. Jang, Polyrhodanine modified anodic aluminum oxide membrane for heavy metal ions removal, J. Hazard. Mater., 187 (2011) 311-317.

[15] X.M. Wang, Y.X. Li, H.G. Li, C.F. Yang, Chitosan membrane adsorber for low concentration copper ion removal, Carbohydrate Polymers, 146 (2016) 274-281.

[16] E. Ntagia, P. Rodenas, A. ter Heijne, C.J.N. Buisman, T. Sleutels, Hydrogen as electron donor for copper removal in bioelectrochemical systems, Int. J. Hydrog. Energy, 41 (2016) 5758-5764.

[17] J. Yang, M.H. Zhou, Y.S. Hu, W.L. Yang, Cost-effective copper removal by electrosorption powered by microbial fuel cells, Bioprocess. Biosyst. Eng., 39 (2016) 511-519.

[18] G. Chen, Electrochemical technologies in wastewater treatment, Sep. Purif. Technol., 38 (2004) 1141.

[19] Q. Wang, L. Huang, Y. Pan, P. Zhou, X. Quan, B.E. Logan, H. Chen, Cooperative cathode electrode and in situ deposited copper for subsequent enhanced $\mathrm{Cd}(\mathrm{II})$ removal and hydrogen evolution in bioelectrochemical systems, Bioresour. Technol., 200 (2016) 565-571.

[20] M. Al-Shannag, Z. Al-Qodah, K. Bani-Melhem, M.R. Qtaishat, M. Alkasrawi, Heavy metal ions removal from metal plating wastewater using electrocoagulation: Kinetic study and process performance, Chem. Eng. J., 260 (2015) 749-756.

[21] E. Bazrafshan, L. Mohammadi, A. Ansari-Moghaddam, A.H. Mahvi, Heavy metals removal from aqueous environments by electrocoagulation process- a systematic review, J. Environ. Health Sci. Eng, 13 (2015) 16.

[22] M.A. Aghdam, H.R. Kariminia, S. Safari, Removal of lignin, COD, and color from pulp and paper wastewater using electrocoagulation, Desalin. Water Treat., 57 (2016) 9698-9704.

[23] H.J. Mansoorian, A.H. Mahvi, A.J. Jafari, Removal of lead and zinc from battery industry wastewater using electrocoagulation process: Influence of direct and alternating current by using iron and stainless steel rod electrodes, Sep. Purif. Technol., 135 (2014) 165-175.

[24] S. Chellam, M.A. Sari, Aluminum electrocoagulation as pretreatment during microfiltration of surface water containing NOM: A review of fouling, NOM, DBP, and virus control, J. Hazard. Mater., 304 (2016) 490-501.

[25] M.S. Matias, S.P. Melegari, D.S. Vicentini, W.G. Matias, C. Ricordel, D. Hauchard, Synthetic wastewaters treatment by electrocoagulation to remove silver nanoparticles produced by different routes, J. Environ. Manage., 159 (2015) 147-157.

[26] B. Zhu, D.A. Clifford, S. Chellam, Comparison of electrocoagulation and chemical coagulation pretreatment for enhanced virus removal using microfiltration membranes, Water Res., 39 (2005) 30983108.

[27] M.Y.A. Mollah, R. Schennach, J.R. Parga, D.L. Cocke, Electrocoagulation (EC) - science and applications, J. Hazard. Mater., 84 (2001) 29-41.

[28] F. Zhang, J. Liu, W. Yang, B.E. Logan, A thermally regenerative ammonia-based battery for efficient harvesting of low-grade thermal energy as electrical power, Energy Environ. Sci., 8 (2015) 343349.

[29] F. Zhang, N. LaBarge, W. Yang, J. Liu, B.E. Logan, Enhancing low-grade thermal energy recovery in a thermally regenerative ammonia battery using elevated temperatures, ChemSusChem, 8 (2015) 10431048.

[30] A.J. Bard, R. Parsons, J. Jordan, Standard potentials in aqueous solution, Taylor \& Francis, 1985.

[31] X. Zhu, M. Rahimi, C.A. Gorski, B. Logan, A thermally-regenerative ammonia-based flow battery for electrical energy recovery from waste heat, ChemSusChem, 9 (2016) 873-879.

[32] T. Kim, M. Rahimi, B.E. Logan, C.A. Gorski, Battery-like reactions to harvest energy from salinity differences using ammonium bicarbonate salt solutions, ChemSusChem, 9 (2016) 981-988.

[33] N. Adhoum, L. Monser, N. Bellakhal, J.-E. Belgaied, Treatment of electroplating wastewater containing $\mathrm{Cu} 2+, \mathrm{Zn} 2+$ and $\mathrm{Cr}(\mathrm{VI})$ by electrocoagulation, J. Hazard. Mater., 112 (2004) 207-213. 
[34] H. Chiu, K. Tsang, R. Lee, Treatment of electroplating wastes, Water Pollut. Control,(GB), 86 (1987) 12.

[35] H.Y. Liu, M. Guo, Y. Zhang, Nitrate removal by $\mathrm{Fe}-0 / \mathrm{Pd} / \mathrm{Cu}$ nano-composite in groundwater, Environ. Technol., 35 (2014) 917-924.

[36] S.A. Mirbagheri, S. Ahmadi, N. Biglari-Joo, Denitrification of nitrate-contaminated groundwater in an anoxic rotating biological contactor: a case study, Desalin. Water Treat., 57 (2016) 4694-4700.

[37] A. Brenner, E.J. Hoekstra, Drinking water quality standards and regulations, Iwa Publishing, London, 2012.

[38] T. Kim, M. Rahimi, B.E. Logan, C.A. Gorski, Harvesting Energy from Salinity Differences Using Battery Electrodes in a Concentration Flow Cell, Environ. Sci. Technol., 50 (2016) 9791-9797.

[39] M.M. Benjamin, Water chemistry, Waveland Press, Incorporated, 2002.

[40] Y. Hong, D.F. Call, C.M. Werner, B.E. Logan, Adaptation to high current using low external resistances eliminates power overshoot in microbial fuel cells, Biosens. Bioelectron., 28 (2011) 71-76.

[41] C.D. Kang, S.J. Sim, Y.S. Cho, W.S. Kim, Process development for the removal of copper from wastewater using ferric/limestone treatment, Korean J. Chem. Eng., 20 (2003) 482-486. 


\section{Graphical Abstract:}

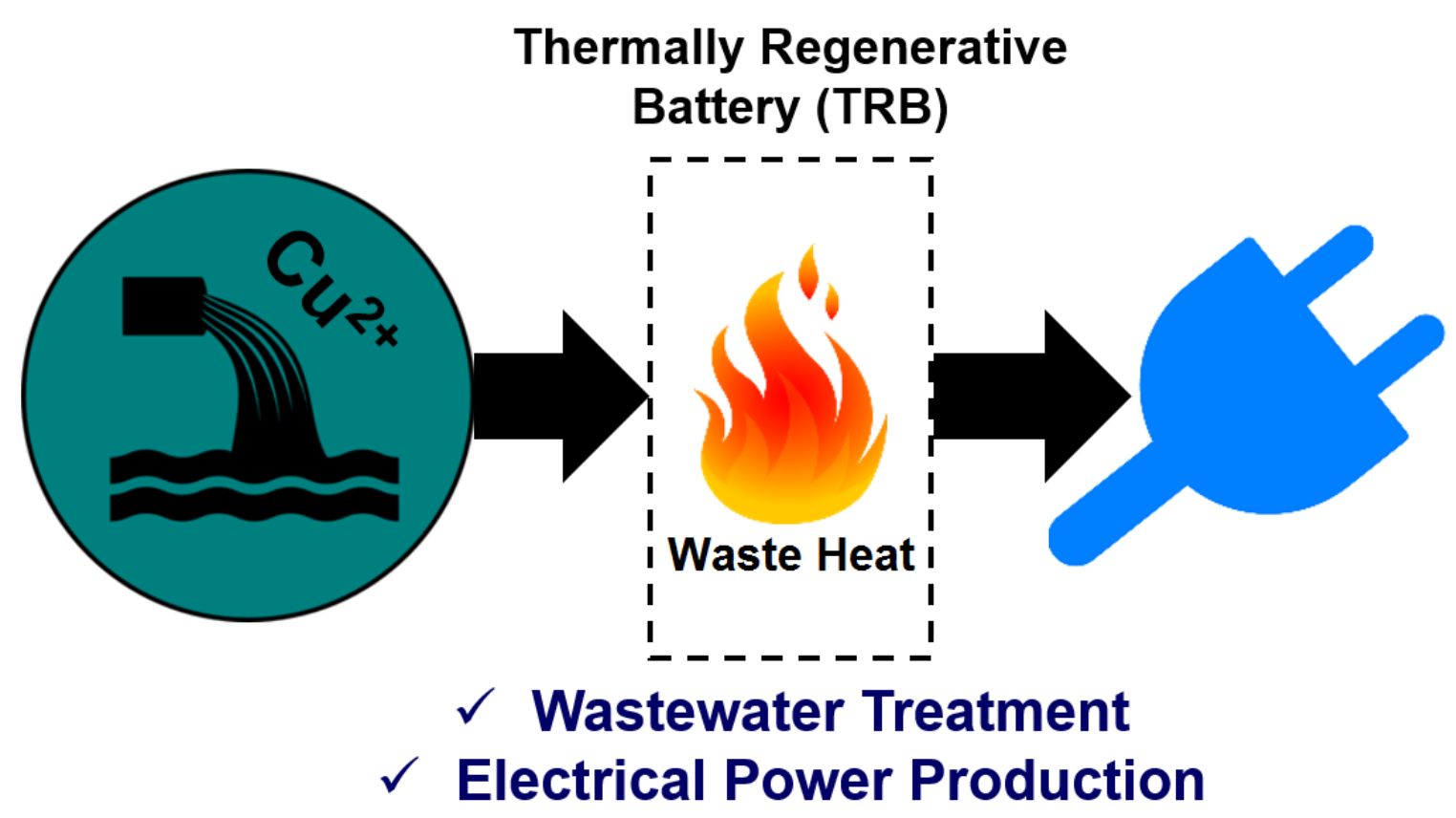




\section{Figures:}

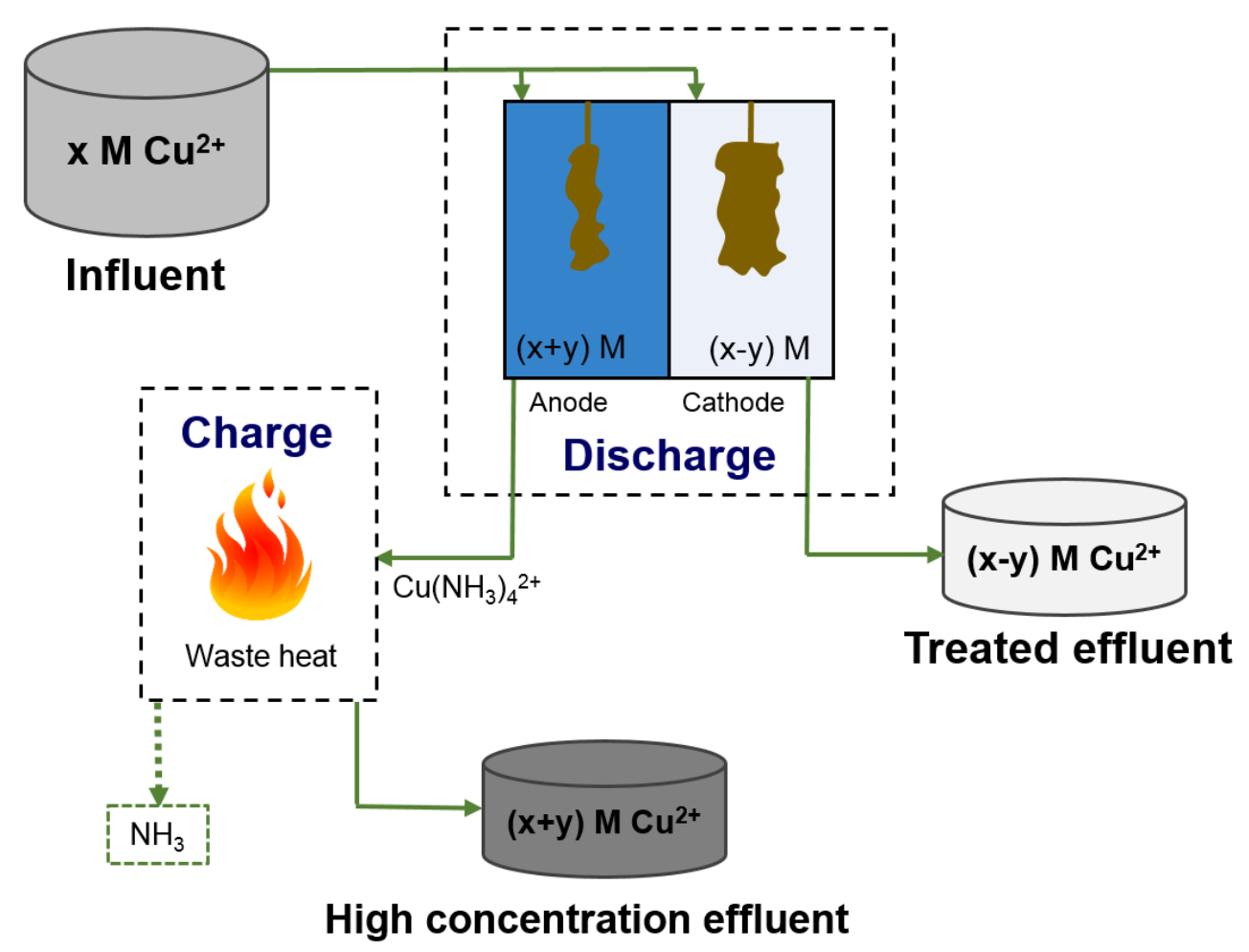

Figure 1. Schematic of the TREB for treatment of copper by dividing the waste stream into high and low concentration streams. Wastewater stream containing certain concentration of copper is introduced to both chambers of TREB, and then by adding ammonia to the anolyte and connecting the external resistance, the battery is discharged. Finally, the waste heat is applied to separate ammonia (Figure S1). The solutions with low and high concentration of copper are then separated. 


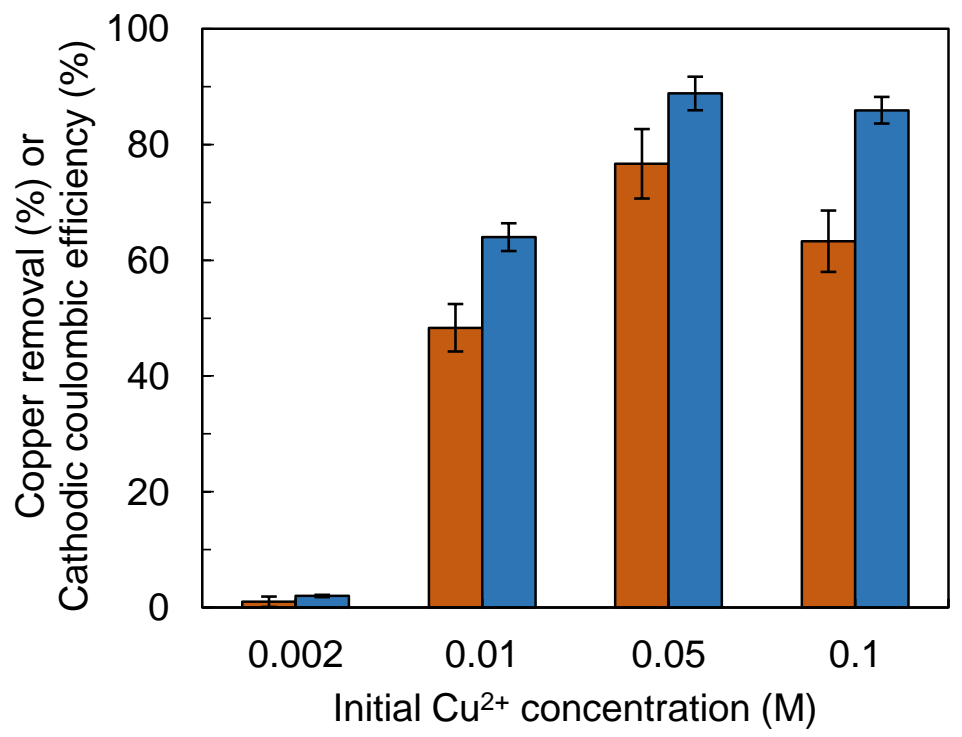

Figure 2. Copper removal from cathode chamber (orange columns), and cathodic coulombic efficacy (blue columns) of TREBs with various copper concentrations, and $1 \mathrm{M}\left(\mathrm{NH}_{4}\right)_{2} \mathrm{SO}_{4}$ supporting electrolyte.

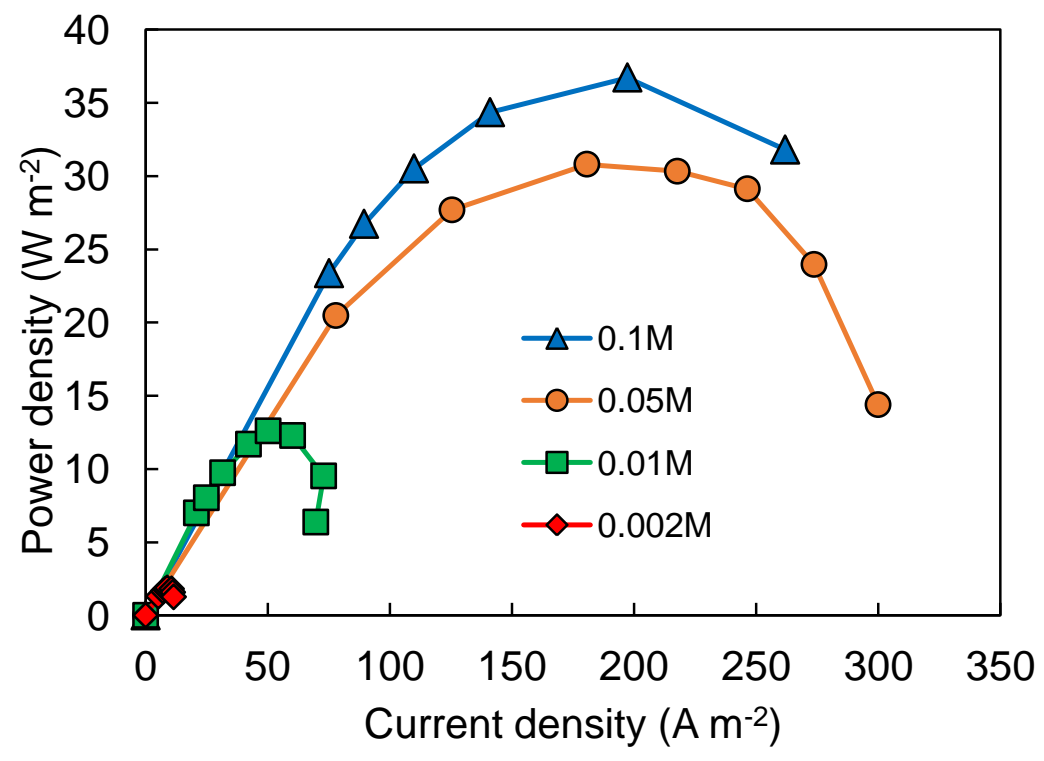

Figure 3. Power densities produced by copper removal using TREBs operated with various concentrations of copper, and $1 \mathrm{M}\left(\mathrm{NH}_{4}\right)_{2} \mathrm{SO}_{4}$ as the supporting electrolyte in both electrolytes, and $2 \mathrm{M}$ ammonia in the anolyte. 
(a)

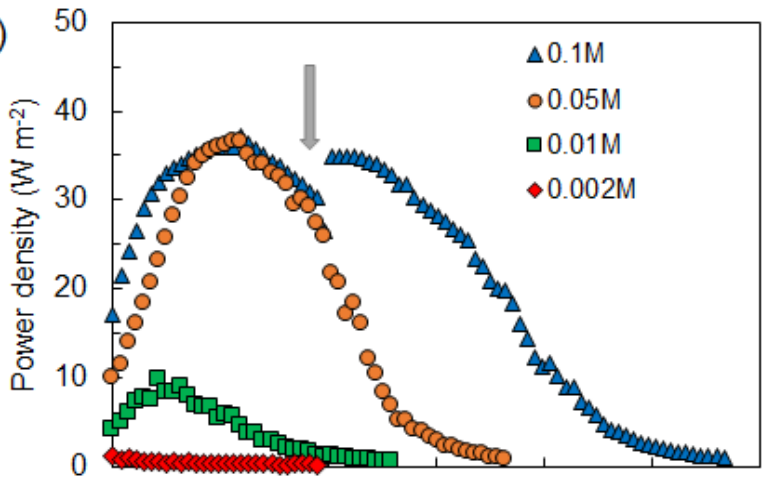

(b)

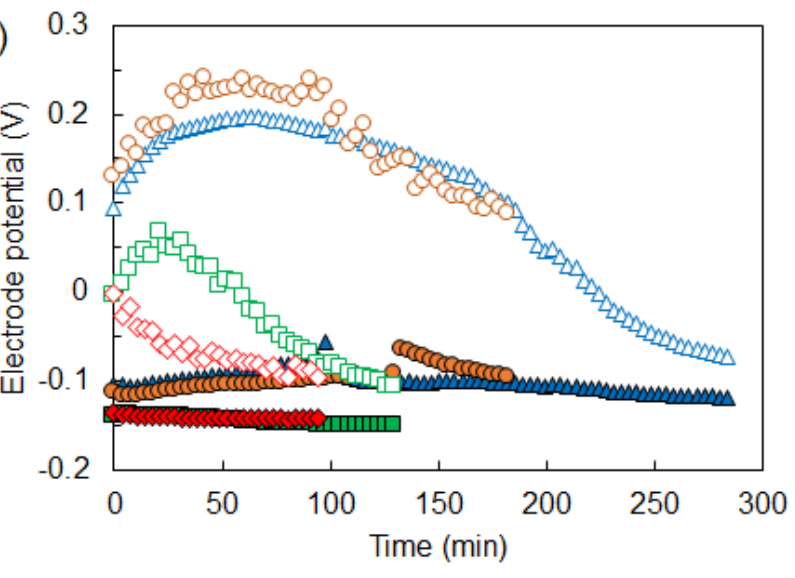

Figure 4. Whole batch cycle performance of copper removal from solutions with different copper concentrations: (a) power densities; (b) cathode (open symbols) and anode (filled symbols) potentials. The initial electrolyte contained a different concentration of $\mathrm{Cu}(\mathrm{II}), 1 \mathrm{M}\left(\mathrm{NH}_{4}\right)_{2} \mathrm{SO}_{4}$, and additional $2 \mathrm{M}$ $\mathrm{NH}_{3}$ in the anolyte, and the cell was operated at its maximum power. The arrow shows when the anode electrode was replaced. 


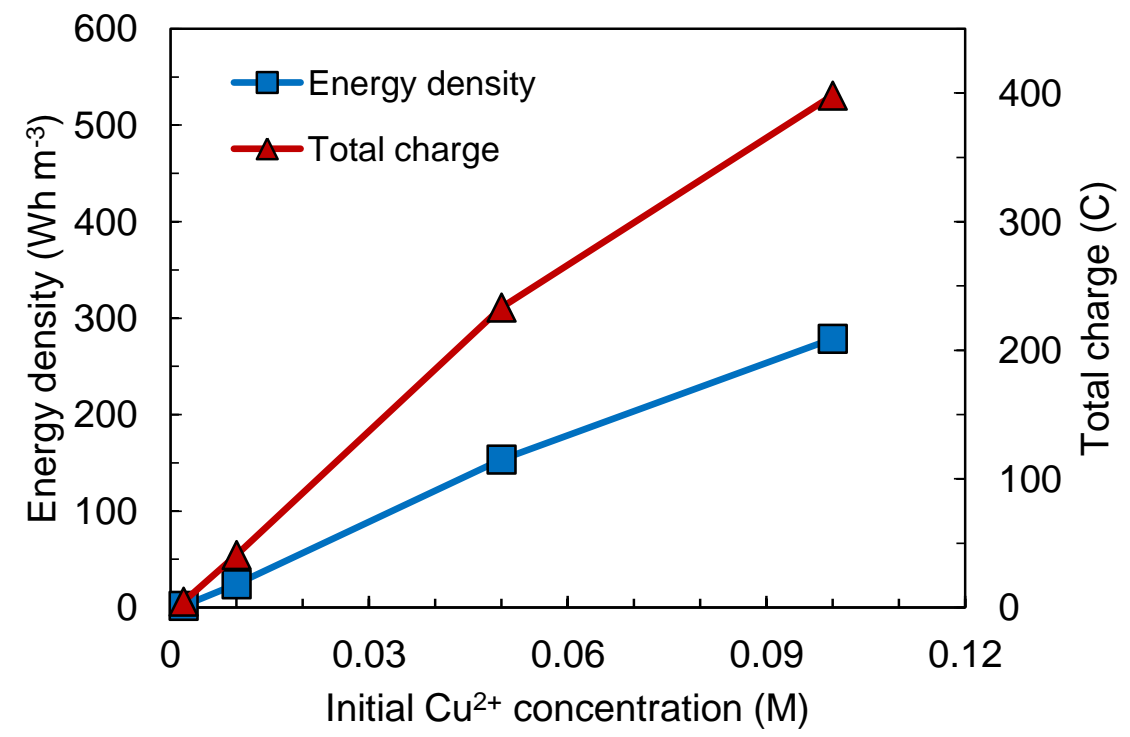

Figure 5. Total charge and corresponding discharge energy densities produced by TREBs operated to remove copper from the catholyte, using $1 \mathrm{M}\left(\mathrm{NH}_{4}\right)_{2} \mathrm{SO}_{4}$ (supporting electrolyte) in both chambers, and additional $2 \mathrm{M} \mathrm{NH}_{3}$ in the anolyte. The cell was operated for maximum power production.

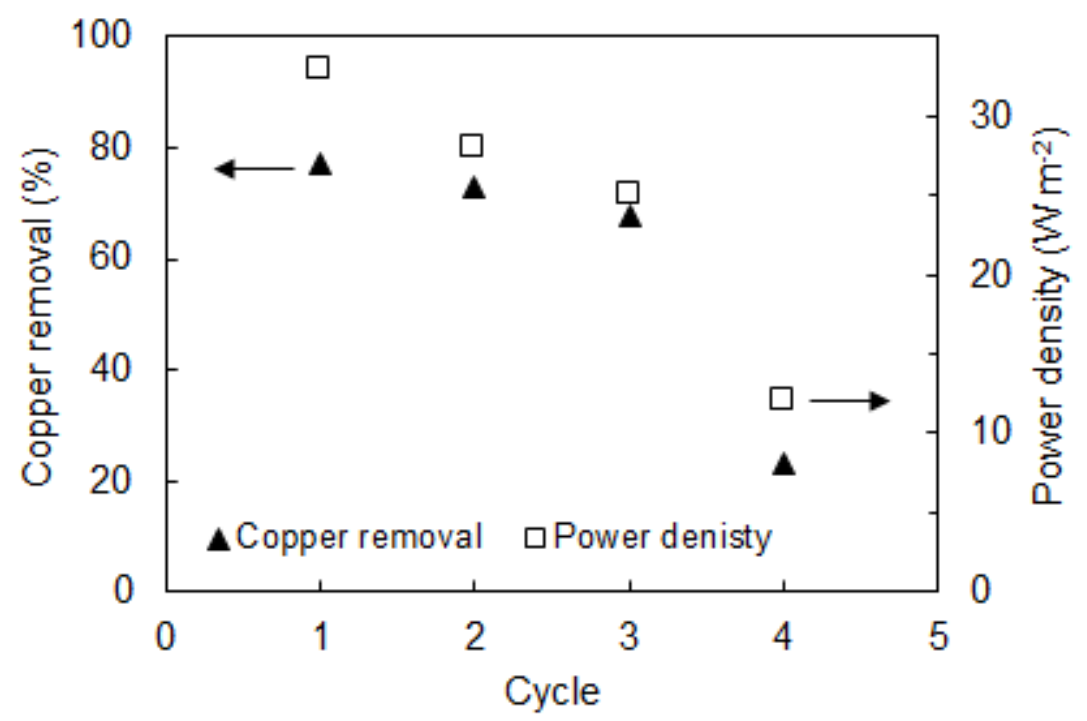

Figure 6. Copper removal and power density of four batch cycles of TREB fed with wastewater with a copper ion concentration of $0.05 \mathrm{M}$. The solution in the anode compartment remained in the chamber, while the catholyte were replaced by a new wastewater after each batch. 